\title{
Antibacterial, antioxidant, antifungal and anti-inflammatory activities of crude extract from Nitraria schoberi fruits
}

\author{
Javad Sharifi-Rad $\cdot$ Seyedeh Mahsan Hoseini-Alfatemi • \\ Majid Sharifi-Rad $\cdot$ Jaime A. Teixeira da Silva
}

Received: 3 September 2014/ Accepted: 31 October 2014/Published online: 13 November 2014

(C) The Author(s) 2014. This article is published with open access at Springerlink.com

\begin{abstract}
This study is the first comprehensive investigation of the antibacterial, antioxidant, antifungal and antiinflammatory activities of a crude extract from Nitraria schoberi L. (Zygophyllaceae) fruits. The extract was tested against four Gram-negative (Pseudomonas aeruginosa, Enterobacter aerogenes, Klebsiella pneumoniae and Acinetobacter lwoffii) and one Gram-positive (Staphylococcus aureus) bacteria using the agar disc diffusion and microdilution methods. $P$. aeruginosa was inhibited the most (widest inhibition zone) while $K$. pneumonia showed the largest MIC value. The antioxidant activity of fruits $(0.02 \mathrm{mg} / \mathrm{mL}$ vs. $0.04,0.06$ and $1.00 \mathrm{mg} / \mathrm{mL}$ for $\alpha$ tocopherol, butylated hydroxyanisole and ascorbic acid, respectively) was determined by the paired diene method. The antifungal activity of $N$. schoberi fruits was tested against different fungi, including Aspergillus niger and
\end{abstract}

J. Sharifi-Rad

Zabol Medicinal Plants Research Center,

Zabol University of Medical Sciences, Zabol, Iran

J. Sharifi-Rad $(\bowtie)$

Department of Pharmacognosy, Faculty of Pharmacy,

Zabol University of Medical Sciences, Zabol, Iran

e-mail: javad.sharifirad@gmail.com

S. M. Hoseini-Alfatemi $(\bowtie)$

Pediatric Infections Research Center, Mofid Children Hospital, Shahid Beheshti University of Medical Sciences, Tehran, Iran e-mail: m.hoseinialfatemi@gmail.com

M. Sharifi-Rad

Department of Range and Watershed Management, Faculty of Natural Resources, University of Zabol, Zabol, Iran

J. A. Teixeira da Silva

Miki-cho Post Office Retired, Ikenobe 3011-2,

P.O. Box 7, Kagawa-ken 761-0799, Japan
Candida albicans, with $300 \mu \mathrm{g} / \mathrm{mL}$ of fruit extract being the most effective concentration. The percentage of antiinflammatory activity assayed for $N$. schoberi fruit extract at 100,200 and $500 \mu \mathrm{g} / \mathrm{mL}$ was $36.12,59.89$ and $88.33 \%$, respectively. $N$. schoberi fruits possess potent antibacterial, antioxidant, antifungal and anti-inflammatory properties, and may be used as an antibacterial and antifungal to treat diseases and/or as a protective agent against disorders associated with oxidative stress and inflammation.

Keywords Agar disc diffusion method - Antifungal activity $\cdot$ Anti-inflammatory activity $\cdot$ Antioxidant activity . Antimicrobial activity $\cdot$ Zygophyllaceae

\section{Abbreviations \\ BHA Butylated hydroxyanisole \\ DMSO Dimethyl sulfoxide \\ MIC Minimal inhibitory concentration}

\section{Introduction}

Plants play a significant role in supplying food for humans. Medicinal and aromatic plants have played a critical role as therapeutic agents for a long time and thus hold great economic value (Balunas and Kinghorn 2005). There is a rising tendency to use natural drugs and herbal therapies, partly because of the destructive nature of and side effects of chemical drugs, as well as environmental pollution (Balunas and Kinghorn 2005; Rad et al. 2013a; Sharifi-Rad et al. 2014). Many naturally occurring agents in plant extracts show antimicrobial, antioxidant, antifungal, anticancer and anti-inflammatory potential in several animal

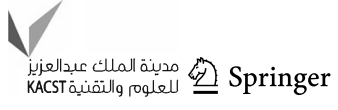


models and bioassay systems, and are pertinent to human disease (Patwardhan 2005; Rad et al. 2014a).

Nitraria schoberi L. (Zygophyllaceae) is a medical plant. Nitraria plants, specifically the leaves, fruits and seeds, are often used in folklore medicine as an antispasmodic, and contain several classes of secondary metabolites including sterols, fatty acids, alkaloids and flavonoids derivatives (Suo and Wang 2010; Hadj et al. 2011). The aims of this study were to investigate the antimicrobial activity of a fruit extract against four Gram-negative and one Gram-positive bacteria as well as its antifungal and anti-inflammatory activities.

\section{Materials and methods}

\section{Preparation of Nitraria schoberi fruit extracts}

Fresh fruits of $N$. schoberi plants (Fig. 1a, b) were collected from Gonabad (coordinates: $34^{\circ} 21^{\prime} 10^{\prime \prime} \mathrm{N}, 58^{\circ} 41^{\prime} 01^{\prime \prime} \mathrm{E}$ ), Razavi Khorasan Province, Iran in June 2013. The plant was taxonomically identified by a botanist at the herbarium of Pharmacognosy, Department of the Faculty of Pharmacy affiliated to Shahid Beheshti University of Medical Sciences of Iran. All fruits were thoroughly washed in distilled water three times then dried in an oven at $75^{\circ} \mathrm{C}$ for $48 \mathrm{~h}$. The dried fruits were powdered by a mechanical grinder and then $20 \mathrm{~g}$ of powdered was dissolved in $200 \mathrm{~mL}$ of $85 \%$ methanol using a shaking water bath $(50 \mathrm{rpm})$ for $24 \mathrm{~h}$ at room temperature. After filtering through Whatman No. 1 filter paper, the filtrate was concentrated with a rotary evaporator (Laborota 4000, Heidolph, Germany) at $45{ }^{\circ} \mathrm{C}$ for $35 \mathrm{~min}$ to remove solvent from the extract. The solidlike material that precipitated (i.e., the extract) was stored at $4{ }^{\circ} \mathrm{C}$ until further analysis.

\section{Microorganisms}

The microorganisms used in this study were obtained from the microbiological laboratory of MRI Hospital in Shiraz (Iran). These bacteria were isolated from MRI patients that provided written permission to do so. Four Gram-negative (Pseudomonas aeruginosa, Enterobacter aerogenes, Klebsiella pneumoniae and Acinetobacter lwoffii) and one Gram-positive (Staphylococcus aureus) bacteria were inoculated onto nutrient agar slants at $37{ }^{\circ} \mathrm{C}$ and maintained at $-80{ }^{\circ} \mathrm{C}$.

Antibiotic discs and microdilution assay

Antimicrobial activity was based on the disc diffusion method (Thitilertdecha et al. 2008) utilizing a separate cell suspension of each microorganism. The concentration of each cell suspension was equilibrated to a $0.5 \mathrm{McF}$ arland standard and $50 \mu \mathrm{L}$ of each microorganism's suspension was spread on a Mueller-Hinton agar plate. In addition, $50 \mu \mathrm{L}$ of diluted fruit extract $(1 \mathrm{~g} / 5 \mathrm{~mL}$ of distilled water) was pipetted onto sterile blank discs (6 $\mathrm{mm}$ in diameter), which were allowed to dry in an open sterile Petri dish in a biological laminar flow bench. Discs were placed on the surface of inoculated plates and incubated at $37{ }^{\circ} \mathrm{C}$ for $24 \mathrm{~h}$. Diameters $(\mathrm{mm})$ of the zones of bacterial inhibition minus the discs diameter were recorded (Aureli et al. 1992). Cephalosporin discs (Padtan Teb Co., Iran) were used as positive controls. Cephalosporin is an antibiotic with antibacterial activity that inhibits cell wall synthesis although some bacteria such as Klebsiella spp., Proteus spp. and Pseudomonas sp. are resistance to it (Wright 2010).

The minimal inhibitory concentration (MIC) values of the plant extract versus each investigated microbial strain
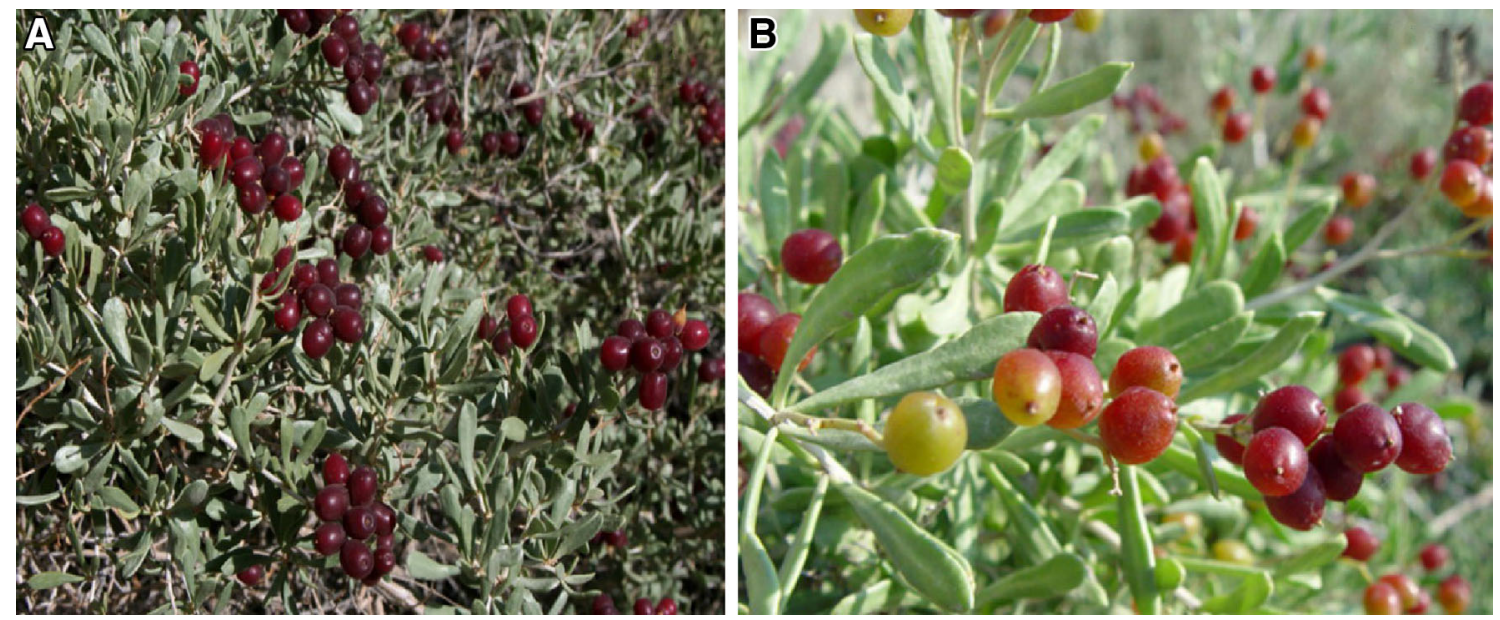

Fig. 1 Nitraria schoberi plant used for extract analyses in this study. a Wild population; b Close-up of plant 
were determined by the microdilution assay in 96 multiwell microtiter plates according to the standard procedure of the Clinical and Laboratory Standards Institute (CLSI 2010). All assays were carried out in Mueller-Hinton Broth (MHB). The plant extract were dissolved in $5 \%$ dimethyl sulfoxide (DMSO) to a final concentration of $10 \mathrm{mg} / \mathrm{mL}$. Each strain was assayed with samples that were serially diluted in broth to obtain concentrations ranging from $512.0,256,128,64,32,16,8,4,2,1,0.5,0.25,0.12$ and $0.06 \mu \mathrm{g} / \mathrm{mL}$. Overnight broth cultures of each strain were prepared and the final microorganism concentration in each well was adapted to $10^{6} \mathrm{CFU} / \mathrm{mL}$. The optimal incubation conditions were $37{ }^{\circ} \mathrm{C}$ for $24 \mathrm{~h}$. The antimicrobial activity to the plant extracts was classified according to the MIC values as follows: MIC $>1,000 \mu \mathrm{g} / \mathrm{mL}$, no antimicrobial activity; $512 \leq$ MIC $\leq 1,000 \mu \mathrm{g} / \mathrm{mL}$, mild activity; 128 $\leq \mathrm{MIC}<512 \mu \mathrm{g} / \mathrm{mL}$, moderate activity; $32 \leq \mathrm{MIC}<$ $128 \mu \mathrm{g} / \mathrm{mL}$, good activity; $10 \leq \mathrm{MIC}<32 \mu \mathrm{g} / \mathrm{mL}$, strong activity; and MIC $<10 \mu \mathrm{g} / \mathrm{mL}$, very strong activity (CLSI 2010). The experiment was carried out in duplicate and the results were expressed as average values.

\section{Antioxidant activity of fruits}

The antioxidant activity of fruits was determined by the paired diene method (Lingnert et al. 1979). The antioxidant activity measured is the capacity of the extract to inhibit the peroxidation of linoleic acid in which the double bond is altered to a paired diene. Each extract sample $(0.01-30 \mathrm{mg} /$ $\mathrm{mL})$ in methanol $(100 \mu \mathrm{L})$ was mixed with $3 \mathrm{~mL}$ of $10 \mathrm{mM}$ linoleic acid (Sigma Chemical Co., St. Louis, MO, USA) to form an emulsion in $0.2 \mathrm{M}$ sodium phosphate buffer ( $\mathrm{pH}$ 6.6) in test tubes and placed in the dark at $37{ }^{\circ} \mathrm{C}$ to hasten oxidation. After incubation for $15 \mathrm{~h}, 7 \mathrm{~mL}$ of $65 \%$ methanol in deionized water was added, and the absorbance of the mixture was measured at $234 \mathrm{~nm}$ against a blank in a Hitachi U-2001 spectrophotometer (Tokyo, Japan). Antioxidant activity was quantified as follows: antioxidant activity $(\%)=\left[\left(\Delta A_{234}\right.\right.$ of control $-\Delta A_{234}$ of sample $) / \Delta A_{234}$ of control] $\times 100$. Analyses were repeated three times. $\alpha$-Tocopherol, butylated hydroxyanisole (BHA) and ascorbic acid (Sigma) were used as standard controls. Antioxidant activity was expressed as the $\mathrm{EC}_{50}$ value $(\mathrm{mg} / \mathrm{mL})$, which is the effective concentration at which the antioxidant activity was inhibited by $50 \%$, gained by interpolation from linear regression analysis.

Antifungal activity

Antifungal activity of $N$. schoberi fruits extracts was assayed against two fungi (Aspergillus niger ATCC 9142 and Candida albicans ATCC 10231). The fungi were cultured at $37^{\circ} \mathrm{C}$ for $14-24 \mathrm{~h}$ and the densities were adjusted to 0.5 McFarland standards at $\mathrm{A}_{530} \mathrm{~nm}\left(10^{8}\right.$ colony-forming units $(\mathrm{CFU}) / \mathrm{mL})$. The antifungal assays were carried out by the disc diffusion method (Bauer et al. 1996). $100 \mu \mathrm{L}$ of the microbial suspensions $\left(10^{8} \mathrm{CFU} / \mathrm{mL}\right)$ was spread on nutrient agar (Merck, Germany) plates $(100 \mathrm{~mm} \times 15 \mathrm{~mm})$. Discs $(6 \mathrm{~mm}$ diameter $)$ were impregnated with $10 \mu \mathrm{L}$ of different concentrations of extract $(50,100,150,200,250$ and $300 \mu \mathrm{g} / \mathrm{mL})$ and placed on the inoculated agar. All the inoculated plates were incubated at $37^{\circ} \mathrm{C}$ for $24 \mathrm{~h}$. Positive control discs comprised ketoconazole $(50 \mathrm{mcg} /$ disc) (Padtan Teb Co., Iran) for fungi. In addition, two microliters of $5 \%(\mathrm{v} / \mathrm{v})$ DMSO was used as the negative control. Antifungal activity was determined by measuring the zone of inhibition (in $\mathrm{mm}$ ).

MIC was determined using serial dilutions of the extract (512- $-0.05 \mu \mathrm{g} / \mathrm{mL}$ ) using the microdilution test confirmed by Clinical and Laboratory Standards Institute (Wayne 2006). The fungal strains were suspended in Luria-Bertani medium and the densities were regulated to $0.5 \mathrm{McF}$ arland standards at $570 \mathrm{~nm}\left(10^{8} \mathrm{CFU} / \mathrm{mL}\right)$. Fungal suspensions $(100 \mu \mathrm{L})$ and extracts were added to microtiter plates and incubated at $37{ }^{\circ} \mathrm{C}$ for $24 \mathrm{~h}$. The sterile control was medium without fungi while the growth control was medium with fungi, but without extract. The growth in each well was compared with that in the control well. MICs were visually detected in comparison with growth of the control well and delineated as the lowest concentration of the extract that inhibited growth.

\section{Anti-inflammatory activity}

The anti-inflammatory activity of $N$. schoberi fruits was tested by the protein denaturation method as described by Padmanabhan and Jangle (2012). Briefly, the reaction included $1 \mathrm{~mL}$ of various concentrations of $N$. schoberi fruits extracts $(100,200$ and $500 \mu \mathrm{g} / \mathrm{mL}$ in distilled water) and $3 \mathrm{~mL}$ of phosphate-buffered saline ( $\mathrm{pH}$ 6.5) which were blended with $2 \mathrm{~mL}$ of egg albumin and incubated at $25^{\circ} \mathrm{C}$ for $15 \mathrm{~min}$. A denaturation reaction was induced in a $65{ }^{\circ} \mathrm{C}$ water bath for $12 \mathrm{~min}$. After cooling, absorbance was measured at $660 \mathrm{~nm}\left(A_{660}\right)$ with a Shimadzu A160 spectrofluorometer (Shimadzu, Japan) using double distilled water as the blank. The percentage inhibition of protein denaturation was appraised by the following formula (Padmanabhan and Jangle 2012):

$\%$ inhibition $=\left[A_{\mathrm{s}}-A_{\mathrm{c}} / A_{\mathrm{c}}\right] \times 100$

where $A_{\mathrm{s}}$ and $A_{\mathrm{c}}$ represent sample and control absorbance, respectively.

In this assay, diclofenac sodium (Padtan Teb Co., Iran), a powerful non-steroidal anti-inflammatory drug, was used as the standard drug in the same concentrations as $N$. schoberi fruit methanol extracts $(100,200$ and $500 \mu \mathrm{g} / \mathrm{mL}$ in distilled water). 
Statistical analysis

The extract was prepared in triplicate for antibacterial, antioxidant, antifungal and anti-inflammatory activities tests. Data were subjected to analysis of variance following a completely random design to determine the least significant difference (LSD) at $P<0.05$ using SPSS v. 11.5 (IBM SPSS, New York, USA).

\section{Results and discussion}

Antibacterial activity

The fruits of $N$. schoberi exhibit varying degrees of inhibition against all bacteria tested (Table 1). Inhibition zones of A. lwoffii, E. aerogenes, K. pneumonia, S. aureus and $P$. aeruginosa were 7, 18, 14, 16 and $25 \mathrm{~mm}$, respectively, indicating that $N$. schoberi fruit extract has a maximum effect on $P$. aeruginosa and a minimum effect on $A$. lwoffii. $P$. aeruginosa and $A$. lwoffii were resistant to cephalosporin (control drug), but sensitive to $N$. schoberi fruit extract (Table 1). The MIC of A. lwoffii, E. aerogenes, K. pneumonia, S. aureus and $P$. aeruginosa was 138, 40, 180, 95

Table 1 Mean diameters of inhibition zone with Nitraria schoberi methanol fruit extract and two positive controls

\begin{tabular}{lcc}
\hline Microorganism & \multicolumn{2}{c}{ Inhibition zone diameter $(\mathrm{mm})$} \\
\cline { 2 - 3 } & Fruit extract & Cephalosporin \\
\hline Acinetobacter lwoffii & $7 \pm 0.05$ & $0 \pm 0.00$ \\
Enterobacter aerogenes & $18 \pm 0.17$ & $5 \pm 0.57$ \\
Klebsiella pneumoniae & $14 \pm 0.08$ & $0 \pm 0.00$ \\
Staphylococcus aureus & $16 \pm 1$ & $4 \pm 0.21$ \\
Pseudomonas aeruginosa & $25 \pm 0.57$ & $0 \pm 0.00$ \\
\hline
\end{tabular}

Values are mean of \pm SE of three replicates and $25 \mu \mathrm{g} / \mathrm{mL}$, respectively. This result confirmed the disc diffusion data since minimum MIC and maximum MIC were related to $P$. aeruginosa and $A$. lwoffii, respectively (Fig. 2).

Bacteria that are resistant to antibiotics may jeopardize medicine. Some such antibiotic-resistant bacteria have greater importance than others, including $S$. aureus, A. lwoffii, E. aerogenes, $K$. pneumonia and $P$. aeruginosa (Chopra 2007). S. aureus, a Gram-positive bacterium, is a highly changeable pathogen in response to antibiotics with considerable importance in human medicine (Alfatemi et al. 2014). It is responsible for a wide range of hospital and community-acquired infections globally, ranging from skin infections and food poisoning to life-threatening situations such as toxic-shock syndrome, endocarditis, pneumonia, bacteremia and osteomyelitis (Kim et al. 2006; Pottinger 2013; Ray et al. 2013; Zecconi and Scali 2013). A. lwoffii is widespread, and a comparatively harmless organism with the ability to persist in a hospital environment for prolonged periods (Rathinavelu et al. 2003; Garn et al. 2013). Enterobacter aerogenes causes bacterial infections, and is usually acquired in a hospital or in hospital-type atmospheres. Enterobacter aerogenes usually brings about opportunistic infections, implying that it will usually only cause an illness in a person or host that has a compromised immune system although studies are now showing that it is causing increased alarm in community infections even though it seldomly causes disease in a person with a healthy immune system (Lavigne et al. 2013). Klebsiella pneumonia, responsible for nosocomial pneumonia in "immunoincompetent" people, produces approximately $10 \%$ of all infections that are acquired in hospitals including urinary tract infections, pneumonia, surgical wounds, and biliary tract wounds (Tam 2013). The most important Gram-negative bacterium is $P$. aeruginosa, which has become a significant cause of infection, particularly in patients with compromised host defense
Fig. 2 MIC values of Nitraria schoberi methanolic fruit extract against five tested bacteria. Values are mean of \pm SE of three replicates. Means with different letters within a column are significantly different $(P<0.05$; LSD $)$

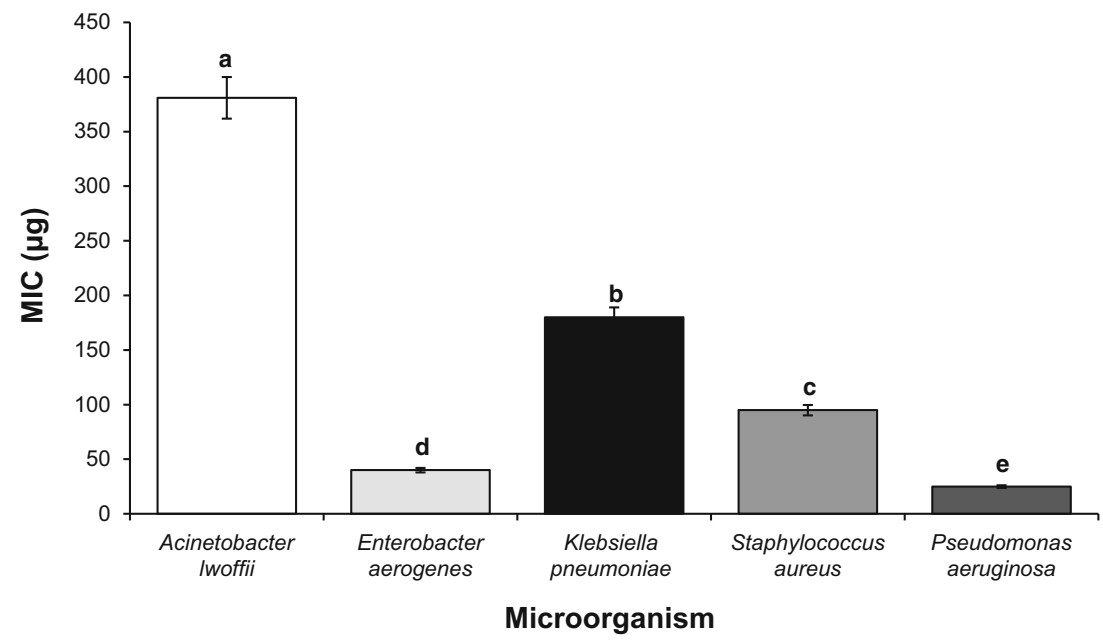


mechanisms (Tepe et al. 2004; Jeyaraj et al. 2013). Pseudomonas aeruginosa is the main and usual pathogen isolated from patients who have been hospitalized for longer than 1 week (Ahmed et al. 2013). It is a frequent cause of nosocomial infections such as pneumonia, urinary tract infections, and bacteremia. Pseudomonal infections are complicated and can be life threatening. Gram-positive bacteria such as $S$. aureus are primarily responsible for post-operative wound infections, toxic-shock syndrome, endocarditis, osteomyelitis and food poisoning (O'Malley et al. 2009).

Studies on the discovery of natural antibacterial sources from plants are increasing. Ahmad and Beg (2001) studied the ethanolic extracts of 45 Indian medicinal plants customarily used for their antimicrobial activity against specific drug-resistant bacteria and a yeast $C$. albicans of clinical origin. 40 of these plant extracts showed different levels of antimicrobial activity against one or more of the assayed bacteria, anticandidal activity was observed in 24 plant extracts while broad-spectrum antimicrobial activity was discovered in 11 plants (Lawsonia inermis, Eucalyptus sp., Holarrhena antidysenterica, Hemidesmus indicus, Casuarina equistifolia, Terminalia belerica, T. chebula, Emblica officinalis, Camelia sinensis, Syzgium aromaticum, and Punica granatum). No similarity was observed between the vulnerability of test strains with plant extracts and antibiotic resistance of the microbial strains (Salmonella paratyphi, Shigella dysenteriae, S. aureus, Bacillus subtilis, Escherichia coli, C. albicans). Qualitative phytochemical examinations, thin layer chromatography (TLC) and a TLC-bioautography of specific active extracts exhibited the presence of ordinary phytocompounds in the plant extracts, including phenols, tannins and flavonoids as the major active components.

Mabona et al. (2013) investigated the antimicrobial characteristics of southern African medicinal plants against dermatologically relevant pathogens. Plants exhibiting noteworthy broad-spectrum activities (MIC values $\leq 1.00 \mathrm{mg} / \mathrm{mL}$ ) against the assayed pathogens comprised extracts from Diospyros mespiliformis, Aristea ecklonii, Chenopodium ambrosioides, Eucalyptus camaldulensis, Elephantorrhiza elephantina, Gunnera perpensa, Harpephyllum caffrum, Melianthus comosus, Hypericum perforatum, Warburgia salutaris and Terminalia sericea. The organic extract of E. elephantina, a plant reportedly used to treat common acne (Propionibacterium acnes), demonstrated considerable antimicrobial activity (MIC $=0.05 \mathrm{mg} / \mathrm{mL}$ ) against $P$. acnes. Similarly, $D$. mespiliformis, traditionally used to treat ringworm, also displayed antimicrobial activity against Trichophyton mentagrophytes $(\mathrm{MIC}=0.10 \mathrm{mg} / \mathrm{mL}$ ) and Microsporum canis (MIC $=0.50 \mathrm{mg} / \mathrm{mL}$ ). The aqueous root extracts of $P$. prunelloides combined with E. elephantina in a $1: 1(\mathrm{v} / \mathrm{v})$ ratio showed synergistic interactions against $S$. aureus, gentamycin-methicillin resistant S. aureus, Staphylococcus epidermidis and $C$. albicans. Fractionation of $A$. ecklonii resulted in the separation of plumbagin, exhibiting remarkable antimicrobial activity in which the MIC ranged from 2.00 to $16.00 \mu \mathrm{g} / \mathrm{mL}$. Rad et al. (2013b) evaluated the antibacterial activity of stem and flower essential oils from Sinapis arvensis on five pathogenic multidrug-resistant bacteria strains by the agar disc diffusion method. The Gram-positive and Gram-negative bacteria that were most susceptible to the stem and flower essential oils of $S$. arvensis were S. aureus (NCTC7428) and P. aeruginosa (MTCC 2453), respectively.

Previous studies have shown that antibacterial activity is caused by various classes of secondary metabolites, including fatty acids, sterols, alkaloids and flavonoids derivatives, flavonoids and phenolic compounds (Tulyaganov and Allaberdiev 2003; Suo and Wang 2010; Hadj et al. 2011). In earlier studies, it was determined that $N$. sibirica fruits contained phenolic compounds (Senejoux et al. 2012).

\section{Antioxidant activity}

The results for antioxidant activity of the extract tested are summarized in Table 2. The efficiency of antioxidant activity is inversely related with the extract's $\mathrm{EC}_{50}$ values. The antioxidant activity, i.e., $\mathrm{EC}_{50}$ values, was $0.04,0.06$, 1.00 and $0.02 \mathrm{mg} / \mathrm{mL}$ for $\alpha$-tocopherol, butylated hydroxyanisole (BHA), ascorbic acid and N. schoberi fruits, respectively (Table 2). The fruit extract was not significantly different to $\alpha$-tocopherol and BHA $(P<0.05)$, but only significantly different to ascorbic acid $(P<0.05)$.

Rad et al. (2014b) investigated the free radical-scavenging and antioxidant activities of different parts of $N$. schoberi plants collected from Zabol, Sistan and Baluchestan Province, Iran. They showed that the maximum free radical and antioxidant activities were associated with

Table $2 \mathrm{EC}_{50}$ values $(\mathrm{mg} / \mathrm{mL})$ of the Nitraria schoberi methanolic fruit extract in two assays

\begin{tabular}{ll}
\hline & Antioxidant activity \\
\hline Fruit extract & $0.02 \pm 0.00 \mathrm{~b}$ \\
$\alpha$-Tocopherol & $0.04 \pm 0.00 \mathrm{~b}$ \\
BHA & $0.06 \pm 0.02 \mathrm{~b}$ \\
Ascorbic acid & $1.00 \pm 0.00 \mathrm{a}$
\end{tabular}

Values are mean of \pm SE of three replicates. Means with different letters within a column are significantly different $(P<0.05$; LSD) 
the methanolic extracts rather than with other extracts (aqueous and chloroform). These activities were maximum in fruits, and lower in leaves and roots. The methanolic, aqueous and chloroform extracts showed 86, 70 and $57 \%$ scavenging activity, respectively. In this study, we investigated the fruits of $N$. schoberi collected from Gonabad, Razavi Khorasan Province, Iran, and also observed antioxidant activity, indicating that this activity remains constant, independent of the geographic location. N. schoberi may be considered a broad and effective source of healthy antioxidants and bioactive phytochemicals.

Choi et al. (2002) evaluated the root bark and leaves of several Korean medicinal plants to appraise their free radical-scavenging capacity and antioxidant activity using common assays with dichloromethane, ethanol or methanol extracts. Flavonoids, including catechin, morin, naringenin, quercetin and rutin, were included and used as standards. Among the plant extracts, the root bark of Morus alba L. and the leaves of Saururus chinensis showed stronger values than other plant extracts.

Bouayed et al. (2007) conducted a comparative study between the leaves of Lavandula officinalis L., the roots of Verbena officinalis L., the flowers of Calylophus lavandulifolius, the leaves of Melissa officinalis L. and the flowers of Althea kurdica plants from the same geographic origin, the Hamadan region in the west of Iran and growing in the same natural conditions. The antioxidant activities differed significantly between all plant parts while some plants were rich in natural antioxidants, especially the leaves of $L$. officinalis and $M$. officinalis.

Nivas et al. (2010) investigated the methanolic extract of young and mature leaves of nine coastal plants from the West coast of Maharashtra, India to appraise their free radical-scavenging activity. The highest antioxidant activity was recorded in young leaves of Hibiscus tiliaceus L. (76 \%), followed by Syzigium corymbosa (71\%), Calophyllum inophyllum L. (68 \%) and Colubrina asiatica (L.) Brongn. (55\%). The leaves of all these species were rich in flavonoids $(6.03-16.63 \mathrm{mg} / \mathrm{g}$ of dry weight) and total polyphenols $(12.12-26.23 \mathrm{mg} / \mathrm{g}$ of dry weight). These compounds mainly contributed to the antioxidant potential of these plants.

The above evidence from the literature suggests that some plants have potent antioxidant activity and free radical-scavenging properties. Plant phenolic compounds have powerful antioxidant activity and may assist in the protection of cells against oxidative damage caused by free radicals, which, with other reactive oxygen species, are a causative factor of different diseases such as asthma, mongolism, arthritis, carcinoma, dementia and Parkinson's disease (Perry et al. 2000).
Table 3 Antifungal activity of Nitraria schoberi fruit extracts against two fungal strains

\begin{tabular}{lrc}
\hline Fruit extract $(\mu \mathrm{g} / \mathrm{mL})$ & Aspergillus niger & Candida albicans \\
\hline 50 & $2.1 \pm 0.0$ & $1.0 \pm 0.0$ \\
100 & $5.6 \pm 0.0$ & $2.5 \pm 0.2$ \\
150 & $9.2 \pm 0.1$ & $6.3 \pm 0.0$ \\
200 & $14.5 \pm 0.0$ & $13.8 \pm 0.0$ \\
250 & $15.7 \pm 0.0$ & $15.1 \pm 0.0$ \\
300 & $18.2 \pm 0.7$ & $17.9 \pm 0.0$ \\
DMSO (negative control) & $1.0 \pm 0.0$ & $0.5 \pm 0.0$ \\
Ketoconazole (positive control) & $14.7 \pm 0.0$ & $21.1 \pm 0.0$ \\
MIC & $284.5 \pm 0.3$ & $342 \pm 0.0$
\end{tabular}

Data are expressed as mean \pm SE of inhibition zone diameter (mm) for different concentration of extract, controls and minimum inhibitory concentration (MIC) $(\mu \mathrm{g} / \mathrm{mL})$

DMSO Dimethyl sulfoxide

Antifungal activity

The antifungal activity of $N$. schoberi fruit extract against two fungi strains is shown in Table 3. Inhibition zones of $A$. niger in response to $50,100,150,200,250$ and $300 \mu \mathrm{g} / \mathrm{mL}$ of fruit extract were 2.1, 5.6, 9.2, 14.5, 15.7 and $18.2 \mathrm{~mm}$, respectively. Inhibition zones of $C$. albicans in response to $50,100,150,200,250$ and $300 \mu \mathrm{g} / \mathrm{mL}$ of fruit extract were $1,2.5,6.3,13.8,15.1$ and $17.9 \mathrm{~mm}$, respectively. DMSO (negative control) and ketoconazole (positive control) showed inhibition zones of $1.0 \mathrm{~mm}$ and $14.7 \mathrm{~mm}$, respectively, for A. niger or $0.5 \mathrm{~mm}$ and $21.1 \mathrm{~mm}$, respectively, for $C$. albicans. The MIC of A. niger and C. albicans was $284 \mu \mathrm{g} / \mathrm{mL}$ and $342 \mu \mathrm{g} / \mathrm{mL}$, respectively.

In the past decade, the prevalence of resistance to antifungal agents has increased. Resistance to antifungal agents has important implications for healthcare, morbidity and mortality in human life. Moreover, a search for new, more secure and potent agents to combat critical fungal infections is required. Plants, especially medicinal plants, are as a good candidate for this aim. In recent years, several studies have been reported on the antifungal activity of phenols, flavonoids, coumarins, quinones, saponins, xanthones, alkaloids, lectins, polypeptides, terpenoids and essential oils from natural sources (Arif et al. 2009). Previous studies showed the presence of secondary metabolites, including alkaloids and flavonoids derivatives, in the Zygophyllaceae (Tulyaganov and Allaberdiev 2003; Hadj et al. 2011).

Anti-inflammatory activity

The results of anti-inflammatory assay of $N$. schoberi fruit extract are shown in Fig. 3: 36.12, 59.89 and $88.33 \%$, 
Fig. 3 Anti-inflammatory effect of Nitraria schoberi fruit extract. Values are mean \pm SE of three replicates; means with different letters within a column are significantly different $(P<0.05 ;$ LSD $)$

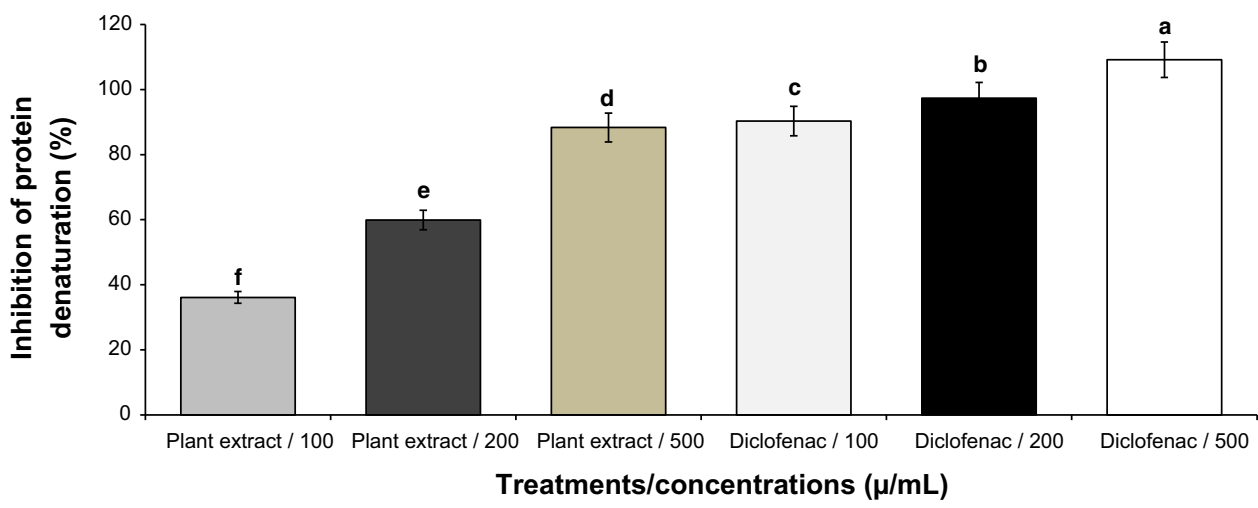

respectively, for 100,200 and $500 \mu \mathrm{g} / \mathrm{mL}$ of $N$. schoberi fruit extract. The anti-inflammatory percentage of diclofenac (control) at 100, 200 and $500 \mu \mathrm{g} / \mathrm{mL}$ was $90.31,97.33$ and $109.13 \%$, respectively. The percentage of inhibition of protein denaturation by $N$. schoberi fruit extracts was significantly different in all treatments $(P<0.05)$.

Inflammation is clinically defined as a pathophysiological procedure described by redness, fever, edema, loss of function and pain (Hyun et al. 2004). Flavonoids possess several biological and pharmacological activities: antimicrobial, anti-inflammatory, immunomodulatory, antiviral, anticancer and antithrombotic activities (Havsteen 1983). Many studies verified that flavonoids possess anti-inflammatory activity in several inflammation animal models. Flavonoids can regulate cellular activities of inflammationrelated cells such as macrophages, lymphocytes, neutrophils and mast cells. For example, some flavonoids inhibit $\mathrm{T}$ cell proliferation while others inhibit the release of histamine from mast cells (Hyun et al. 2004).

\section{Conclusion}

Nitraria schoberi fruits show promising use as new pharmaceuticals with antibacterial, antioxidant, antifungal and anti-inflammatory activities. Even so, organic compounds and active agents in the fruits need to be identified for the plant to be used as herbal drug while the toxicity of the active components, serum-attainable levels, pharmacokinetic attributes, their side effects, and diffusion in various sites around the body also need to be determined. Nitraria schoberi fruits decreased and inhibited the growth of food pathogens. Therefore, use of this plant might decrease food poisoning and increase food shelf life.

Acknowledgments The authors are very grateful to Department of Range and Watershed Management, Faculty of Natural Resources, University of Zabol for supports in this study.
Conflict of interest The authors declare no financial or other conflicts of interest.

Open Access This article is distributed under the terms of the Creative Commons Attribution License which permits any use, distribution, and reproduction in any medium, provided the original author(s) and the source are credited.

\section{References}

Ahmad I, Beg AZ (2001) Antimicrobial and phytochemical studies on 45 Indian medicinal plants against multi-drug resistant human pathogens. J Ethnopharmacol 74(2):113-123. doi:10.1016/ S0378-8741(00)00335-4

Ahmed Z, Khan SS, Khan M (2013) In vitro trials of some antimicrobial combinations against Staphylococcus aureus and Pseudomonas aeruginosa. Saudi J Biol Sci 20(1):79-83. doi:10. 1016/j.sjbs.2012.10.005

Alfatemi SMH, Rad JS, Rad MS, Mohsenzadeh S, Teixeira da Silva JA (2014) Chemical composition, antioxidant activity and in vitro antibacterial activity of Achillea wilhelmsii C. Koch essential oil on methicillin-susceptible and methicillin-resistant Staphylococcus aureus spp. 3 Biotech. doi: 10.1007/s13205-0140197-x

Arif T, Bhosale JD, Kumar N, Mandal TK, Bendre RS, Lavekar GS, Dabur R (2009) Natural products- antifungal agents derived from plants. J Asian Nat Prod Res 11(7):621-638. doi:10.1080/ 10286020902942350

Aureli P, Constantini A, Zolea S (1992) Antimicrobial activity of some plant essential oils against Listeria monocytogenes. J Food Prot 55:344-348

Balunas MJ, Kinghorn AD (2005) Drug discovery from medicinal plants. Life Sci 78(5):431-441. doi:10.1016/j.1fs.2005.09.012

Bauer AW, Kirby WMM, Sherris JC, Turck M (1996) Antibiotic susceptibility testing by a standardized single disk method. Am J Clin Pathol 45(4):493-496

Bouayed J, Piri K, Rammal H, Dicko A, Desor F, Younos C, Soulimani R (2007) Comparative evaluation of the antioxidant potential of some Iranian medicinal plants. Food Chem 104(1):364-368. doi:10.1016/j.foodchem.2006.11.069

Choi CW, Kim SC, Hwang SS, Choi BK, Ahn HJ, Lee MY, Park SH, Kim SK (2002) Antioxidant activity and free radical scavenging capacity between Korean medicinal plants and flavonoids by assay-guided comparison. Plant Sci 163(6):1161-1168. doi:10. 1016/S0168-9452(02)00332-1 
Chopra I (2007) The increasing use of silver-based products as antimicrobial agents; a useful development or a concern. J Antimicrob Chemother 59(4):587-590. doi:10.1093/jac/dkm006

CLSI (2010) Performance standards for antimicrobial susceptibility testing: 20th informational supplement. CLSI document M100S20. Clinical and Laboratory Standards Institute, Wayne

Garn H, Neves JF, Blumberg RS, Renz H (2013) Effect of barrier microbes on organ-based inflammation. J Allergy Clin Immunol 131(6):1465-1478. doi:10.1016/j.jaci.2013.04.031

Hadj SJ, Chevalot I, Harscoat-Schiavo C, Paris C, Fick M, Humeau C (2011) Biological activities of flavonoids from Nitraria retusa (Forssk.) Asch. and their acylated derivatives. Food Chem 124(2):486-494. doi:10.1016/j.foodchem.2010.06.059

Havsteen B (1983) Flavonoids, a class of natural products of high pharmacological potency. Biochem Pharmacol 32(7):1141-1148. doi:10.1016/0006-2952(83)90262-9

Hyun E, Bolla M, Steinhoff M, Wallace JL, Soldato PD, Vergnolle N (2004) Anti-inflammatory effects of nitric oxide-releasing hydrocortisone NCX 1022, in a murine model of contact dermatitis. Br J Pharmacol 143(5):618-625. doi:10.1038/sj.bjp.0705854

Jeyaraj M, Varadan S, Anthony KJP, Murugan M, Raja A, Gurunathan S (2013) Antimicrobial and anticoagulation activity of silver nanoparticles synthesized from the culture supernatant of Pseudomonas aeruginosa. J Ind and Eng Chem 19(4):1299-1303. doi:10.1016/j.jiec.2012.12.031

Kim JS, Song W, Kim HS, Cho HC, Lee KM, Choi MS, Kim EC (2006) Association between the methicillin resistance of clinical isolates of Staphylococcus aureus, their staphylococcal cassette chromosome mec (SCCmec) subtype classification and their toxin gene profiles. Diagn Microbiol Infect Dis 56(3):289-295. doi:10.1016/j.diagmicrobio.2006.05.003

Lavigne JP, Sotto A, Nicolas-Chanoine MH, Bouziges N, Pagès JM, Davin-Regli A (2013) An adaptive response of Enterobacter aerogenes to imipenem: regulation of porin balance in clinical isolates. Int J Antimicrob Agents 41(2):130-136. doi:10.1016/j. ijantimicag.2012.10.010

Lingnert H, Vallentin K, Eriksson CE (1979) Measurement of antioxidative effect in model system. J Food Process Pres 3(2):87-103. doi:10.1111/j.1745-4549.1979.tb00574.x

Mabona U, Viljoen A, Shikanga E, Marston A, Van Vuuren S (2013) Antimicrobial activity of southern African medicinal plants with dermatological relevance: From an ethnopharmacological screening approach, to combination studies and the isolation of a bioactive compound. J Ethnopharmacol 148(1):45-55. doi:10. 1016/j.jep.2013.03.056

Nivas D, Sonar BA, Shaikh SS, Patil UH, Gaikwad DK, Chavan NS, Sabale AB, Chavan PD (2010) Screening of some coastal plant resources for their antioxidant potential, total polyphenol and flavonoid content. Pharmacognosy J 2(7):151-156. doi:10.1016/ S0975-3575(10)80083-5

O’Malley M, Fowler J, Ilyas AM (2009) Community-acquired methicillin-resistant Staphylococcus aureus infections of the hand: prevalence and timeliness of treatment. J Hand Surg 34(3):504-508. doi:10.1016/j.jhsa.2008.11.021

Padmanabhan P, Jangle SN (2012) Evaluation of in vitro antiinflammatory activity of herbal preparation, a combination of four herbal plants. Int J Basic Appl Med Sci 2(1):109-116

Patwardhan B (2005) Ethnopharmacology and drug discovery. J Ethnopharmacol 100(1-2):50-52. doi:10.1016/j.jep.2005.06.006

Perry G, Raina AK, Nunomura A, Wataya T, Sayre LM, Smith MA (2000) How important is oxidative damage lessons from Alzheimer's disease. Free Radic Biol Med 28(5):831-834. doi:10.1016/S0891-5849(00)00158-1

Pottinger PS (2013) Methicillin-resistant Staphylococcus aureus infections. Med Clin North Am 97(4):601-619. doi:10.1016/j. mena.2013.02.005
Rad JS, Alfatemi SH, Rad MS, Iriti M (2013a) In-vitro antioxidant and antibacterial activities of Xanthium strumarium L. extracts on methicillin-susceptible and methicillin-resistant Staphylococcus aureus. Ancient Sci Life 33:109-113. doi:10.4103/02577941.139050

Rad JS, Alfatemi SMH, Rad MS, Sen DJ (2013b) Phytochemical and antimicrobial evaluation of the essential oils and antioxidant activity of aqueous extracts from flower and stem of Sinapis arvensis L. Am J Adv Drug Deliv 1(1):001-010

Rad JS, Alfatemi SMH, Rad MS (2014a) In vitro assessment of antibacterial activity of Salicornia herbacea L. seed extracts against multidrug resistant gram-positive and gram-negative bacteria. Int. J Biosci 4(6):217-222. doi:10.12692/ijb/4.6.217-222

Rad JS, Alfatemi SMH, Rad MS, Iriti M (2014b) Free radical scavenging and antioxidant activities of different parts of Nitraria schoberi L. TBAP 4(1):44-51

Rathinavelu S, Zavros Y, Merchant JL (2003) Acinetobacter lwoffii infection and gastritis. Microb Infect 5(7):651-657. doi:10.1016/ S1286-4579(03)00099-6

Ray GT, Suaya JA, Baxter R (2013) Microbiology of skin and soft tissue infections in the age of community-acquired methicillinresistant Staphylococcus aureus. Diagn Microbiol Infect Dis 76(1):24-30. doi:10.1016/j.diagmicrobio.2013.02.020

Senejoux F, Girard C, Aisa HA, Bakri M, Kerram P, Berthelot A, Bévalot F, Demougeot C (2012) Vasorelaxant and hypotensive effects of a hydroalcoholic extract from the fruits of Nitraria sibirica Pall. (Nitrariaceae). J Ethnopharmacol 141(2):629-634. doi:10.1016/j.jep.2011.08.012

Sharifi-Rad J, Hoseini-Alfatemi SM, Sharifi-Rad M, Setzer WN (2014) Chemical composition, antifungal and antibacterial activities of essential oil from Lallemantia royleana (Benth. in Wall.) Benth. J Food Safety. doi:10.1111/jfs.12139

Suo Y, Wang L (2010) Extraction of Nitraria tangutorum seed lipid using different extraction methods and analysis of its fatty acids by HPLC fluorescence detection and on-line MS identification. Eur J Lipid Sci Technol 112(3):390-399

Tam PYI (2013) Approach to common bacterial infections: community-acquired pneumonia. Pediatr Clin North Am 60(2):437-453. doi:10.1016/j.pcl.2012.12.009

Tepe B, Donmez E, Unlu M, Candan F, Daferera D, Vardar-Unlu G, Polissioud M, Sokmen A (2004) Antimicrobial and antioxidative activities of the essential oils and methanol extracts of Salvia cryptantha (Montbret et Aucher ex Benth.) and Salvia multicaulis (Vahl). Food Chem 84(4):519-525. doi:10.1016/S03088146(03)00267-X

Thitilertdecha N, Teerawutgulrag A, Rakariyatham N (2008) Antioxidant and antibacterial activities of Nephelium lappaceum L. extracts. LWT-Food. Sci Technol 41(10):2029-2035. doi:10. 1016/j.lwt.2008.01.017

Tulyaganov TS, Allaberdiev FK (2003) Alkaloids from plants of the Nitraria genus. Structure of sibiridine. Chem Nat Compd 39(3):292-293. doi:10.1023/A:1025482821368

Wayne PA (2006) Clinical and Laboratory Standards Institute, CLSIM7-A7. 7th edn. Clinical and Laboratory Standards Institute (CLSI). Methods for dilution antimicrobial susceptibility tests for bacteria that grow aerobically; approved standard

Wright GD (2010) Antibiotic resistance in the environment: a link to the clinic? Curr Opin Microbiol 13(5):589-594. doi:10.1016/j. mib.2010.08.005

Zecconi A, Scali F (2013) Staphylococcus aureus virulence factors in evasion from innate immune defenses in human and animal diseases. Immunol Lett 150(1-2):12-22. doi:10.1016/j.imlet. 2013.01.004 